Canadian Journal of Family and Youth, 13(2), 2021, pp. 190-194

ISSN 1718-9748@ University of Alberta

http://ejournals,library,ualberta.ca/index/php/cjfy

\title{
Jolly, Joanna. (2019). Red River Girl: The Life and Death of Tina Fontaine. Toronto: Viking Press.
}

Reviewed by: Kaitlyn Isberg, MacEwan University

Canada is recognized as a country of multiculturalism and for accepting individuals regardless of their heritage. However, Indigenous people often find themselves outside this definition as they are subject to neglect and discrimination by Canada's government and justice system. The book "Red River Girl" by Joanna Jolly is a true-crime biography that depicts the short and tragic life of Indigenous schoolgirl Tina Fontaine. On August 17, 2014, Tina Fontaine's lifeless body was discovered in Winnipeg's Red River when police were looking for the body of Faron Hall despite Tina being a missing person for a week. Cases regarding Indigenous people often do not receive attention; however, Tina's murder grasped the nation's attention as the CFS (Child and Family Services) failed to protect her, and she was involved in substance abuse and sexual exploitation.

The book presents the 2014 national figures collected by the Royal Canadian Mounted Police that "estimated that nearly 1,200 Indigenous women had been murdered or gone missing between 1980 to 2012" (p. 23). However, the Native Women Association of Canada had collected figures and "showed that the number of those murdered or missing nationally over the last forty years was closer to four thousand" (p. 23). Negligence towards Indigenous people stems from 
government-funded residential schools. The schools operated from the 1970s to 1996; the estimation is that 150,000 Indigenous children were placed in these schools to fulfill the slogan 'kill the Indian in the child.' The residential schools' effects are still prevalent in the Indigenous community as the trauma is generational as many survivors resort to a high-risk lifestyle. In the book, Thelma Favel states, "I know hundreds of both men and women who were abused and neglected in the residential schools and now serve addictions from drugs and alcohol" (pp. 241242). The residential school's impact has been passed down through generations as the survivors use substances to cope with their pain and trauma. Substance addiction often results in negligence or abuse towards their children; thus, these children themselves turn to substances or the streets, creating a vicious cycle.

Tina Fontaine's life compares to the generational side effects of residential schools. Tina's biological mother, Valentina Duck, also referred to as Tina, is a drug addict and a prostitute. On October 31, 2011, when Tina was twelve, her father, Eugine Fontaine, was on a three-day alcohol binge with friends, got in an argument with them and was violently murdered. When Tina's dad died, she and her sister Sarah ended up in full-time care of their auntie Thelma Favel and her husband, Joseph Favel.

After the murder of Eugine, Tina asked Thelma to reconnect with her surviving parent Valentia in Winnipeg, Manitoba, about $130 \mathrm{~km}$ from her residence in Powerview. Thelma was reluctant to let Tina go with her mother for a week in late June, but the CFS assured Thelma that they would have check-ins at Valentina's home, which they did not. Tina's sister Sarah was supposed to accompany her to visit their mother but "suddenly changed her mind saying that she 
didn't feel comfortable with Valentina" (p. 46). Tina's previously innocent life deteriorated into a high-risk lifestyle due to her depressive mental state and reintroduction with her mother. Valentina introduced Tina to selling her body for money and then using that money towards crystal meth. Valentia Duck was also under accusation for beating Tina and kicking her on the street, leaving her homeless.

During Tina's time in the city, she became acquainted with Raymond Cormier, also referred to as Sebastian, when she was walking down the street with her boyfriend, Cody Mason. The couple struck up a conversation and informed Raymond that they had no place to sleep; he then provided them with a place to stay. Tina and Raymond's friendship began to bloom after this interaction despite the forty-year age difference. However, this friendship quickly became toxic; Raymond often provided the young girl with marijuana, crystal meth, crack cocaine, alcohol, and gabbies, the street name for the epilepsy drug gabapentin. Furthermore, Tracy Beardy and her fifteen-year-old sister Chantelle confirmed that Raymond discussed having sexual relations with Tina despite her being under the age of consent.

On December 8, 2015, Raymond Cormier was under arrest for the murder of Tina Fontaine. "January 29, 2018, the trial of the Queen versus Raymond Joseph Cormier opened in central Winnipeg... he entered a plea of not guilty" (p. 253). The evidence against Raymond consisted of having ownership of the same duvet that Tina's dead body was placed in along with rocks to keep her body submerged. Sergeant John O'Donovan created a project called STYX where undercover police officers were pretending to be Raymond's friend attempting to get a recorded confession to Tina's murder; his house was also tapped with microphones. The tapes handed to the jury were from project STYX and consisted of Raymond stating the following: 
When I found out, that was it. Said I'm not going to bang her no more. Don't overdose here cause then your body's going to be wrapped up in a fucking carpet and thrown into the river. It's right on the shore. So, what do I do? Threw her in. Unfortunately, there's a little girl in a fucking grave someplace screaming at the top of her lungs for me to fucking finish the job. And guess what.. I finished the job (pp. 265-266).

However, the jury found Raymond not guilty as the charges were based on speculation, not fact and that the tapes were merely the police's understanding of them.

The book outlines two other families, the Osborn and Bushie family, who, similar to Tina, never received justice from the Canadian courts. Colton Bouchie was with friends when their car broke down, so they stopped at a farmyard to receive help when the house owner Gerald Stanly shot Colton in the head, killing him instantly; however, he was proven not to be guilty of seconddegree murder. The Indigenous leaders accused the RCMP of issuing a statement that "focused more on the fact that Bouchie's friends had been accused of theft than it did on the young man's killing, making the shooting look as though it was justified" (p. 255). The Osborne family had five relatives disappear and were never found. Similar to the Osborne relatives, Tina went unnoticed as a missing person despite being reported five times from June 30th to August 17th. Cornelis Brock Jansen and Constable Craig Houle flagged Richard Mohammed for picking up Tina off the street for sexual relations. However, the officers claim they let her go as they did not acknowledge the missing person report on her profile due to the officer's lack of experience.

Furthermore, the book outlines a common practice in Saskatoon, Saskatchewan, called starlight tours. Indigenous people are arrested by police officers and transported out of the city perimeters to be beaten and left to die. Moreover, Indigenous people also face neglect regarding their living conditions. As stated in the book, they live in "the third world conditions" (p. 271). 
These third-world conditions on the reserves consist of no electricity, no clean drinking water or water at all, and no easy access to food.

Despite the sad story of Tina Fontaine and the other innocent Indigenous lives who never received justice, I enjoyed reading "Red River Girl” because I found it very educational and informative about an important issue in Canadian society. Joanna Jolly raises awareness for the Indigenous community by presenting an abundance of information with in-depth detail within her writing and discusses a delicate subject with composure. Although Canada is a multicultural country, it must be more proficient in advocating for the Indigenous people's rights as they are subject to neglect and discrimination. Academic disciplines that may find it beneficial to read the book "Red River Girl” include social work, sociology, history, law, as well as arts and cultural studies. I would recommend this book to all Canadian citizens, as it is essential to be informed about how individuals in your community are placed at a disadvantage and treated differently solely based on their ethnicity. 